\title{
Managing the Stress of War and Terrorism: Guidelines for Families
}

\section{Suzanna Smith ${ }^{2}$}

War and terrorism are scary for children and families. Children of all ages may overhear adult conversations or see acts of war or terror on the news. These events are unsettling and stressful for children and their parents. Stress makes it hard to concentrate and go about daily routines. Stress that lasts a long time can hurt an individual's and family's health. On the other hand, children and their families can learn to be resilient in times of stress. They can bounce back from hard times, and become even stronger.

\section{Signs of Stress Overload for Adults}

- Tired all the time

- Can't concentrate

- Have trouble sleeping (too much or too little)

- Use alcohol or drugs more

- Lash out at friends and family

- Have tension headaches, stomach aches, or lower back pains

- Feel depressed, anxious, or helpless

\section{Signs of Stress for Children and Teens}

- Express feeling afraid or scared

- Grades drop suddenly

- Extra clingy or needy

- Go back to behaviors they've outgrown (bed wetting, thumb sucking)

- Withdraw from others

\section{Signs of Stress in Families}

- More disagreements that aren't solved

- Family members pull apart from each other

- Family members become too close and clingy

- Blaming one or two family members for problems

- More problems with children, like unruly behavior or poor school performance

1. This document is FCS9200, one of a series of the Department of Family, Youth and Community Sciences, Florida Cooperative Extension Service, IFAS, University of Florida, Gainesville FL 32611. First published: May 2003. Reviewed by Elizabeth Bolton, Ph.D., Department of Family, Youth and Community Sciences. Please visit the EDIS Web site at http://edis.ifas.ufl.edu

2. Suzanna Smith, Ph.D., associate professor, Department of Family, Youth and Community Sciences, University of Florida, Gainesville FL 32611. 


\section{What families can do to manage stress and become resilient}

- Listen to children. Don't push aside their fears. Answer their questions and let them share their feelings. Tell them that you will do everything you can to help them stay safe.

- Talk with others. Don't withdraw. Tell adult family members and friends about your feelings.

- Follow daily family routines and work together. Children thrive on predictable patterns of waking, eating, working, and sleeping. All children like to feel that they are important to their family. Work together to get things done.

- Spend time together. Make your home a fun, welcoming and emotionally safe place. Do things together as a family, such as games and outdoor activities.

- Take time to relax. Cut down on stressful activities. (It is especially important that children not be exposed to war news coverage.) Schedule times to do whatever you find relaxing.

- Get physical. Regular exercise reduces stress. Walk, bike, garden, work out.

- Avoid alcohol and cigarettes. These cloud your judgment and lower your energy.

- Think positive. Try to be optimistic about the future. Remember that your family and the country have survived hard times before. Seek spiritual support in whatever ways help you.

- Follow emergency plans. Put together an emergency kit and be aware of disaster plans. Feeling in control is helpful in a stressful situation.

- Get professional help. If you are overwhelmed, depressed, have thoughts of suicide, or have a substance abuse problem, find a professional you can talk to. Your doctor, clergy or mental health association can assist you find someone who is trained to help.

\section{References}

American Psychological Association (2003). Resilience in a time of war (series). Retrieved from http:/helping.apa.org/resilience/war.html.

National Mental Health Association (2003). Dealing with the stress of war. Retrieved from http://www.nmha.org/reassurance/waitingforwar.cfm

Smith, S. \& Pergola, J. (2003). Stress Management (series). Retrieved from http://edis.ifas.ufl.edu/TOPIC_Stress_Management. 